\title{
Study circles improve the precision in nutritional care in special accommodations
}

\author{
Albert Westergren'*, Carolina Axelsson', Petra Lilja-Andersson', \\ Christina Lindholm', Karin Petersson ${ }^{2}$ and Kerstin Ulander ${ }^{\prime \dagger}$ \\ 'Department of Clinical Nursing Science, School of Health and Society, Kristianstad University College, Kristianstad, \\ Sweden; ${ }^{2}$ Department of Food and Restaurant, Social Service, Municipality of Kristianstad, Kristianstad, Sweden
}

\section{Abstract}

Background: Disease-related malnutrition is a major health problem in the elderly population, but it has until recently received very little attention, especially are management issues under-explored. By identifying residents at the risk of undernutrition (UN), appropriate nutritional care can be provided.

Objective: To investigate if study circles and policy documents improve the precision in nutritional care and decrease the prevalence of low or high body mass index (BMI).

Design: Pre and post-intervention study.

Setting: Special accommodations (nursing homes) within six municipalities were involved.

Participants: In 2005, 1,726 (90.4\%) of 1,910 residents agreed to participate and in 2007, 1,526 (81.8\%) of 1,866 residents participated.

Intervention: Study circles in one municipality, having a policy document in one municipality and no intervention in four municipalities.

Measurements: Risk of UN was defined as involving any of: involuntary weight loss; low BMI; and/or eating difficulties. Overweight was defined as high BMI.

Results: In 2005 and 2007, 64\% and 66\% of residents, respectively, were at the risk of UN. In 2007, significantly more patients in the study circle municipality were accurately provided protein and energy enriched food (PE-food) compared to the no intervention municipalities. There was a decrease between 2005 and 2007 in the prevalence of low BMI in the study circle municipality, but the prevalence of overweight increased in the policy document municipality.

Conclusions: Study circles improve the provision of PE-food for residents at the risk of UN and can possibly decrease the prevalence of low BMI. It is likely that a combination of study circles and implementation of a policy document focusing on screening and on actions to take if the resident is at UN risk can give even better results.

Keywords: education; malnutrition; undernutrition; overweight; special accommodation; quality improvement

Received: 4 February 2009; Revised: 7 July 2009; Accepted: 3I August 2009; Published: 23 September 2009

$\mathrm{M}$ alnutrition (undernutrition (UN) and overweight) is a major health problem in the elderly population (1), but has until recently received very little attention. Management issues in malnutrition are also under-explored.

In a previous study, $27 \%$ of residents $(n=1,726$, mean age 85) in special accommodations (SAs) had a moderate or high risk of $\mathrm{UN}$, fulfilling at least two of three criteria

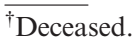

(involuntary weight loss, body mass index (BMI) below limit, and/or eating difficulties), and 30\% were overweight or obese (1). In another study, $32 \%$ of residents $(n=566$, mean age 84$)$ in SAs were at UN risk (based on Malnutrition Universal Screening Tool, MUST) (2). UN among elderly is associated with increased morbidity and mortality and is thus important to intervene against (3) with suitable actions, such as providing oral supplements and/or protein and energy enriched food (PE-food). 
Not only factors among the residents, but also the staff knowledge and attitudes, and environmental and organizational factors in the institution influence the UN-risk (4). For example, UN is 'taboo' and connected with feelings of shame and guilt for the staff. This might cause the staff to be unaware of or to neglect the problem (5). Confused role expectations (4), problems with food services (6), poor quality of environment, lack of knowledge, and a shortage of staff can further increase the UN-risk (3).

It is important to educate the staff in SAs about simple interventions that could improve nutritional status (3), especially as it has been found that a majority (64\%) of residents at UN-risk do not receive any form of nutritional support (2). Nutrient dense food, or PE-food, and oral supplements can improve nutritional status and reduce mortality in elderly at UN-risk (3, 7-10). Besides these interventions, family style meals have been found to stimulate energy intake and protect nursing home residents against UN, most likely due to improved ambience, social interaction, group effect, and food choice (11). Furthermore, education programs focusing on nutrition can improve the ability of nursing staff to ensure adequate food intake for their residents $(12,13)$. To our knowledge, and after a PubMed search (July 2009, search strategy: study circle and undernutrition), no studies have focused on how well-nutritional interventions are targeted to those at UN-risk after implementation of study circles.

Kitson and colleagues (14) state that 'successful implementation' (SI) of new ideas (evidence, guidelines, etc.) is a function ( $\mathrm{f}$ ) of the interrelations between three key elements - evidence (E), context (C), and facilitation $(\mathrm{F}): \mathrm{SI}=\mathrm{f}(\mathrm{E}, \mathrm{C}, \mathrm{F})$. Thus, an educational intervention considering these three elements might be successful in increasing the precision in the nutritional interventions, which will in turn hopefully decrease the number of residents with a low BMI, an indicator of UN-risk, without increasing the occurrence of overweight. Study circles focusing on eating and nutrition might be one such successful educational intervention.

Study circles have previously been used in healthpromoting activities $(15,16)$. Because of its simple, flexible structure, and its capacity to address contextual factors, the study circle could serve as a model for educational interventions. The basic principle of study circles can be described by the motto 'The participant is an expert' and the overall aim is to identify key problems and learn how to master them (15).

The aim of this study was to explore in a large-scale study if study circles or having a policy document change the precision in nutritional care and the prevalence of low or high BMI.

\section{Present investigation}

\section{Materials and methods}

Subjects

All SAs ( $n=65$ units) within six municipalities, belonging to the same geographical region in southern Sweden, were involved in two-point prevalence studies in November 2005 and October 2007. In 2005, 1,726 (90.4\%) of 1,910 residents agreed to participate and in $2007,1,526$ $(81.8 \%)$ of 1,866 residents participated. In 2005, the mean age was slightly higher ( 85.8 years (SD 7.6) versus 85.4 years (SD 7.7)) among those not participating compared to those included $(P=0.043)$. There was no significant difference regarding gender between those included and those not participating.

The municipalities were divided into three groups, no intervention (four municipalities), study circles (one municipality), and policy document (one municipality). In 2005 and 2007, 1,084 and 973 residents participated in municipalities with no intervention, in the municipality with study circles 467 and 384 participated, and in the municipality with a policy document 175 and 169 , respectively.

Data collection

After gaining informed consent, students, clinical tutors, and staff collected the data during five days (MondayFriday).

Undernutrition (UN) and overweight

UN-risk was defined as the occurrence of involuntary weight loss, and/or BMI below limit $(<20$ if $\leq 69$ years, $<22$ if $\geq 70$ years), and/or eating difficulties according to the Minimal Eating Observation Form - Version II (MEOF-II) (17) based on Swedish recommendations for detecting UN-risk $(1,18)$. MEOF-II includes three components of eating. Ingestion includes 'manipulation of food on the plate,' 'transport of food to the mouth,' and 'sitting position.' Deglutition includes 'ability to chew,' 'manipulation of food in the mouth,' and 'swallowing.' Energy includes 'alertness,' 'appetite,' and 'eating $<3 / 4$ of served food' (17).

Overweight was graded based on BMI (if $\leq 69$ years: BMI 25 or above: if $\geq 70$ years: BMI 27 or above) and so was obesity (if $\leq 69$ years: BMI $30-39$ : if $\geq 70$ years: BMI 32-41) and severe obesity (if $\leq 69$ years: BMI $>40$ : if $\geq 70$ years: BMI $>42$ ) (1).

Height and weight were measured by using the standard equipment available at the particular units. Information about unintentional weight loss was gained from the patient or estimated from previous weight.

Oral supplements

Oral supplements include oral nutritional supplements, such as protein and energy drinks given in addition to 
and chiefly between the main meals. Supplements do not include pharmacological therapy or drug supplement with multivitamin and mineral pills.

Precision in nutritional care

The 'precision in nutritional care' describes the relationship between nutritional treatment (PE-food, oral supplements, and eating assistance) and UN-risk. The precision is here divided into:

- perfect targeting (at UN-risk and provided with treatment AND not at UN-risk and not provided with treatment);

- at UN-risk and provided with treatment;

- not at UN-risk and not provided with treatment;

- under-treatment (at UN-risk but not provided with treatment); and

- over-treatment (not at UN-risk but provided with treatment).

Interventions

Study circles. In one municipality, 39 study circles, each consisting of eight staff members (in total 315 participants), were carried out. Each study circle met for three afternoons (three hours each time). The most common combination of staff in each circle was one person working in the kitchen, who is the most often also, was the circle leader, and seven auxiliary nurses or nurse assistants. No dietitian was involved in the study circles as there was no one employed in the municipalities. Inspired by Kitson and colleagues' (14) ideas about the three key elements (evidence, context, and facilitation) for a SI of evidence and knowledge into practice, the study circle (SC) intervention is described here.

Evidence. The discussions within the study circles were guided by a manual developed by Elisabet Rothenberg and Albert Westergren (19). Six themes were discussed: (1) the importance of food for the care recipient, (2) that it can be difficult to eat, (3) routines, tools, and responsibility, (4) food as medicine, (5) food hygiene, and (6) when the mealtime becomes a question of life and death. Connected to each theme were references made to chapters in two books from the National Food Administration $(20,21)$, as well as scientifically based texts online, written by researchers within the field (19). The study circles did not focus on the above definition of UNrisk or overweight specifically.

Context. The staff members attending each study circle most often came from the same unit. The pedagogical method included the identification of specific nutritionally related problems that the participants decided to discuss and a 'brain storming' about ways to solve the problem in their own context, at their own unit. A structured plan of action was developed in order to achieve the necessary changes. The participants were encouraged to use the power of the group to achieve the changes (15). More than one study circle could be held at each unit.

Facilitation. The project leaders for the study circles (AW and KP) coordinated and continually evaluated (every six months) the circles. They also ordered and distributed the material and had discussions with the politicians and the managers. The intervention was supported by the management. Thus, managers ensured that the staff got time to prioritize the study circles. The study circle leader acted as a facilitator for the participants. The role of the study circle leader was to administer the circles, to facilitate discussions and to ensure that the participants focused on the issues. The study circle leader was not an expert in the field, but got a one-day introduction in the circle leader task.

Policy document

After the first nutritional survey (in 2005), a policy document was politically anchored in one municipality and thereafter implemented in the organization without having been planned within the study framework.

No intervention

There was no specific nutritional intervention in the other four municipalities other than that the results from the nutritional survey in 2005 was sent to each unit with a possibility for the staff to compare their own unit's results with the total results from the other municipalities. The same feedback was provided to the policy document and study circle municipalities. Through a nutritional network (the Network for Eating and Nutrition in North-East Skåne, NEN-NES) between the municipalities, hospitals and primary health care, having meetings four times each year, no other major changes (catering, nursing system, or organizational) in the 'no intervention' municipalities came to the authors' knowledge.

\section{Ethics}

The ethical guidelines for conducting scientific work were followed. This study was approved in each municipality. The respondents were asked for informed consent. Both verbal and written information was given and respondents were guaranteed anonymity, i.e. no personal identification number or names were collected. Formal approval by an ethical committee was not required for this kind of study according to local and national directives.

Analysis

Parametric and non-parametric statistics were used depending on the level of data and based on unpaired 
comparisons between two or three groups. The following tests were applied: Chi-square test, Kruskal-Wallis test, Mann-Whitney $U$-test, $T$-test, and one-way ANOVA. The level of statistical significance was set at $p<0.05$. When multiple comparisons were made (going from three to two group comparisons), a reduced $p<0.017$ was used to avoid mass significance (type I or alpha error) (22). Analyses were performed using SPSS version 16.0 (SPSS Inc., Chicago, IL, USA).

\section{Results}

During the two years that the study was conducted, there was a significant decrease in the number of residents with low BMI while there was a significant increase in the number of residents with unintentional weight loss in the total sample. There was also a significant increase in residents fulfilling two or three criteria for UN-risk. In $2005,63.7 \%$ of residents were at UN-risk and in 2007 the equivalent number was $65.7 \%(p<0.0005)$. There was a significant increase in the use of PE-food and oral supplements between the two years (Table 1).

There were no significant differences in 2005 and 2007 between the three groups regarding age, gender, UN-risk criteria, and overweight (Table 2).

In 2005 , at baseline, more residents $(17.2 \%)$ at UN-risk in the policy document municipality were provided with oral supplements compared to in the no intervention $(10.5 \%, p<0.010)$ and study circle municipalities $(8.5 \%$, $p=0.002)$. Otherwise there were no differences in the precision of nutritional care at baseline (Table 3).

In 2007, the perfect targeting in provision of PE-food (residents not at UN-risk do not get PE-food while residents at UN-risk are provided with PE-food) was significantly higher in the study circle municipality (48.5\%) compared to in the no intervention municipalities $(38.1 \%, p<0.001)$. Likewise, more residents at UNrisk were provided with PE-food in the study circle municipality $(12.6 \%)$ compared to in the no intervention municipalities $(6.1 \%, p<0.001)$ and the under-treatment was less frequent (study circle $49.7 \%$, no intervention municipalities $61.3 \%, p<0.001)$. In 2007 , the over-treatment with PE-food or oral supplements (treatment provided despite that the resident is not at UN-risk) was generally low, varying between 0.6 and $3.2 \%$. Overtreatment with oral supplements was more common in the study circle municipality $(3.2 \%)$ compared to in the no intervention municipalities $(1.0 \%, p=0.008)$ (Table 3$)$.

Between 2005 and 2007, there was no change in the number of residents with low or high BMI in the no intervention municipalities. There was a significant decrease in the number of residents with low BMI in the study circle municipality, while there was a significant increase of residents with high BMI in the policy document municipality (Table 4).
Table 1. Characteristics of respondents in special accommodations in $2005(n=1,726)$ and $2007(n=1,526)$

\begin{tabular}{|c|c|c|c|}
\hline & $\begin{array}{l}\text { Year } \\
2005\end{array}$ & $\begin{array}{c}\text { Year } \\
2007\end{array}$ & $P$-value \\
\hline \multicolumn{4}{|l|}{ Characteristics of residents } \\
\hline Age, mean (SD) & $\begin{array}{c}85.4 \\
(7.7)\end{array}$ & $\begin{array}{c}85.8 \\
(7.6)\end{array}$ & 0.043 \\
\hline$<70$ years $(\%)$ & 4.0 & 3.3 & 0.105 \\
\hline$\geq 70$ years $(\%)$ & 96.0 & 96.7 & \\
\hline Gender, men (\%) & 31.0 & 32.1 & 0.493 \\
\hline \multicolumn{4}{|l|}{ Criteria for UN-risk (\%) } \\
\hline Having eating difficulties according to MEOF-II & 53.4 & 52.3 & 0.521 \\
\hline Low $\mathrm{BMI}^{\mathrm{a}}$ & 30.1 & 26.1 & 0.019 \\
\hline Unintentional weight loss & 19.4 & 35.8 & 0.001 \\
\hline Fulfilling risk criteria (\%) & & & 0.001 \\
\hline No criteria - no risk & 36.4 & 34.3 & \\
\hline One criteria - low risk & 37.5 & 35.9 & \\
\hline Two criteria - moderate risk & 18.0 & 23.3 & \\
\hline Three criteria - high risk & 8.2 & 6.5 & \\
\hline Overweight ${ }^{b}(\%)$ & & & 0.090 \\
\hline No overweight & 70.0 & 67.0 & \\
\hline Grade I, overweight & 21.4 & 24.3 & \\
\hline Grade 2, obesity & 8.3 & 8.5 & \\
\hline Grade 3, severe obesity & 0.2 & 0.3 & \\
\hline \multicolumn{4}{|l|}{ Nutritional support (\%) } \\
\hline Eating assistance & 50.5 & 48.8 & 0.320 \\
\hline PE-food & 4.5 & 9.1 & 0.001 \\
\hline Oral supplements & 11.2 & 16.3 & 0.001 \\
\hline
\end{tabular}

${ }^{\mathrm{a}} \mathrm{BMI}<20$ (69 years or below), $\mathrm{BMI}<22$ (70 years or older).

bOverweight: 25-29 (69 years or below), 27-31 (70 years or older); obesity: 30-39 (69 years or below), 32-4I (70 years or older); severe obesity: $>40$ (69 years or below), $>42$ (70 years or older).

Note: Analyses: T-test, Chi-square test, and Mann-Whitney $U$-test. PE-food: protein and energy enriched food.

\section{Discussion}

The study circle intervention increased the precision in the provision of PE-food for residents at UN-risk in comparison to the no intervention municipalities and there was also a decrease in the prevalence of low BMI between 2005 and 2007. The over-treatment with PE-food or oral supplements was low (0.6-3.2\%). Over-treatment with oral supplements was more common in the study circle municipality than in the no intervention municipalities. In the policy document municipality there was an increase in the number of residents with high BMI between 2005 and 2007. No improvements were seen neither in the precision of provision of PE-food or oral supplements for respondents at UN-risk nor in low BMI in the no intervention or policy document municipalities.

The 'naturalistic study design' used in this study can be put in contrast to studies with a randomized-controlled 


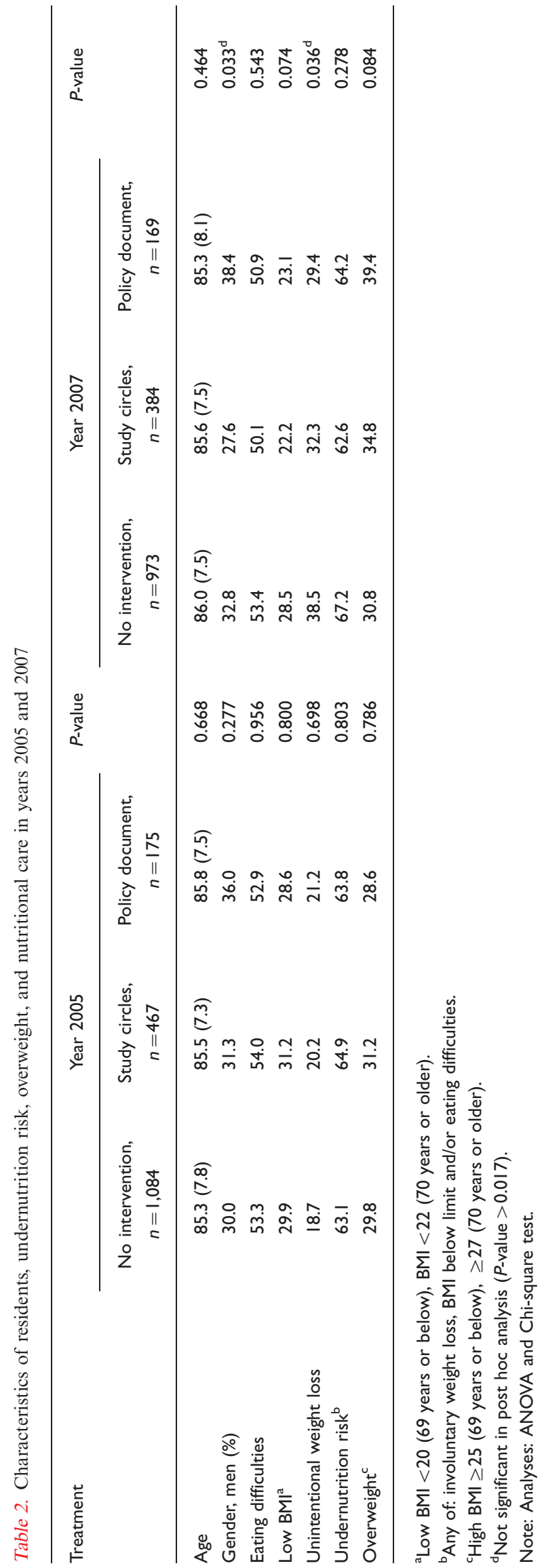

design. For instance, in a randomized-controlled smallscale study ( $n=88$ divided into four groups) oral supplements were found to increase daily protein and energy intake, and increase weight among nursing home residents (23). In such a study almost everything 'is under control.' Besides such studies, it is also important to find out if similar results can be achieved in large-scale studies under more naturalistic circumstances, i.e. in daily clinical practice, as was done in this study.

It can be difficult to control the impact of factors outside the control of the study. For instance, in one municipality a policy document was implemented without having been planned within the study framework. However, results from the respondents in the policy document municipality were used as a separate intervention group. Also other unknown factors could have influenced the results; however, such factors would most likely also have affected the municipalities without intervention. In addition, the large-scale format of the study might have evened out some of the external influencing factors.

Surprisingly, there was an increase in the prevalence of unintentional weight loss in the total sample while there was a decrease in the number of residents with low BMI. When discussing the results with the staff in the municipalities, they explained this with an increased awareness about the importance of following the weight development of the residents since the first study in 2005 . Thus, the increase in the prevalence of unintentional weight loss depends on an increased frequency of weighing the residents and thus an increased awareness of possible weight loss. This means that the prevalence of UN-risk in 2007 is probably more accurate than the figures given for 2005 .

The fairly positive changes achieved should not only be interpreted as a result of the increased precision in provision of PE-food alone. Most likely, other multifaceted interventions, planned within the study circles, contributed to the positive outcome. Interventions improving ambience, cooperation with the kitchen staff, better food to each resident, changes in routines, and improved knowledge and attitudes among the staff are likely to have contributed as well. Some other studies support this conclusion. In one study it was found that changes in food service and dining room environment increased the food intake among cognitively impaired residents with low BMI (24). In another study it was shown that a multifaceted nutritional intervention (chocolate, homemade supplements, group exercise, and oral care) among nursing home residents had a positive influence on nutrition and functioning (25). In a third study, nutritional education to professionals had positive effects on the nutrition of residents in dementia wards (26). One important contributing factor for achieving positive outcomes is that evidence, facilitation as well as 


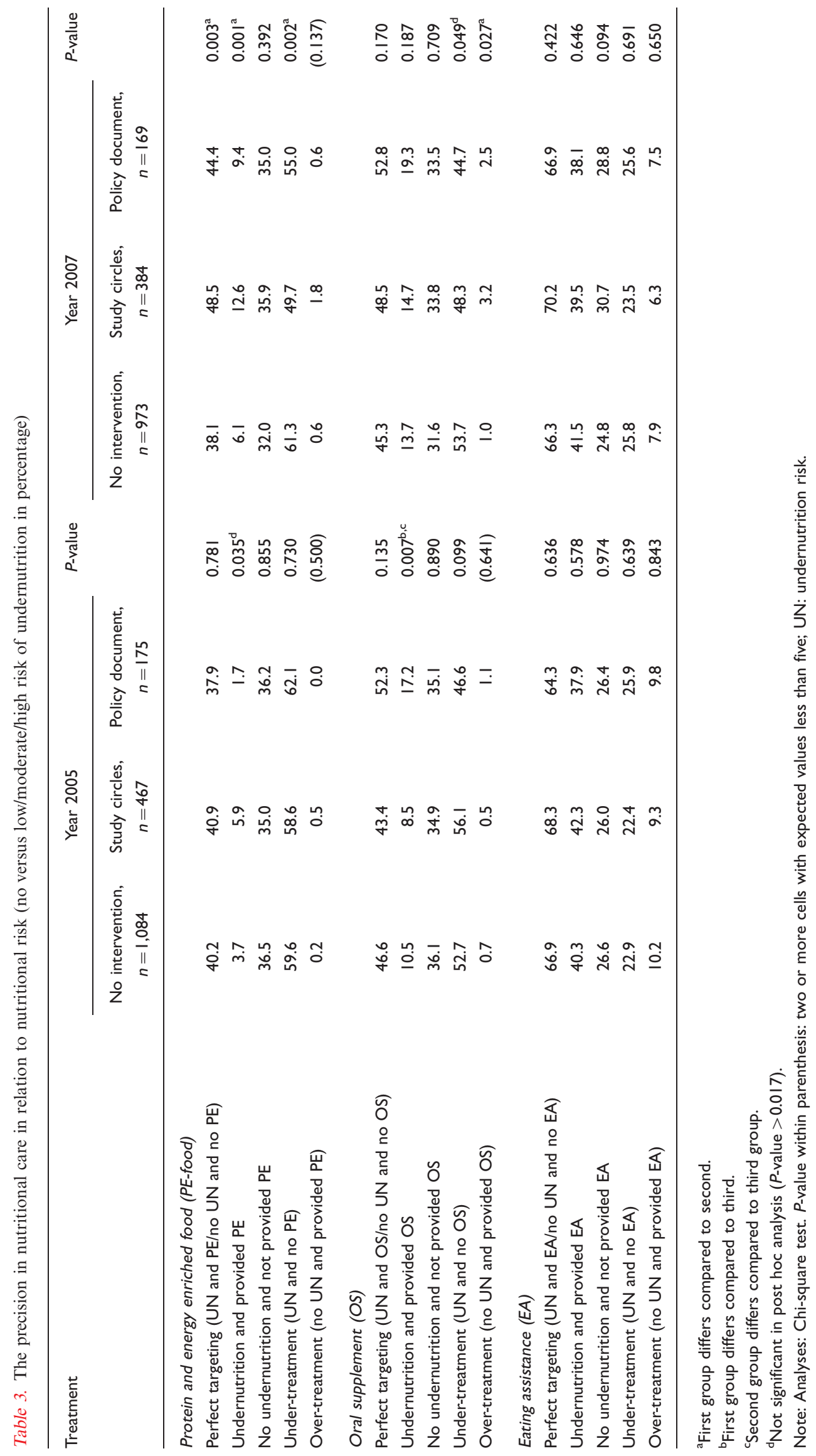


Table 4. Prevalence (\%) of low and high BMI in 2005 and 2007 for different interventions

\begin{tabular}{llll}
\hline & $\begin{array}{l}\text { Year 2005 } \\
n=I, 726\end{array}$ & $\begin{array}{l}\text { Year 2007 } \\
n=I, 526\end{array}$ & $P$-Value \\
\hline No intervention & $n=I, 084$ & $n=973$ & \\
Low BMI & 29.9 & 28.5 & $0.5 I I$ \\
High BMI & 29.8 & 30.8 & 0.656 \\
Study circles & $n=467$ & $n=384$ & \\
Low BMI & $3 I .2$ & 22.2 & 0.007 \\
High BMI & $3 I .2$ & 34.8 & 0.294 \\
Policy document & $n=175$ & $n=169$ & \\
Low BMI & 28.6 & 23.1 & 0.256 \\
High BMI & 28.6 & 39.4 & 0.037 \\
\hline
\end{tabular}

Note: Analyses: Chi-square test. Low BMI $<20$ (69 years or below), $\mathrm{BMI}<22$ (70 years or older). High BMI $\geq 25$ (69 years or below), $\geq 27$ (70 years or older).

the context is taken into account in the intervention methods (14).

A few residents at no UN-risk received PE-food and oral supplements. This should not be interpreted as 'low precision' or strictly as over-treatment based on the data from this study. The explanation for these findings can be that these elderly were regarded as being at risk due to other reasons than those covered here. Thus, such actions can have been taken to prevent someone from developing UN-risk. However, when intervening against malnutrition there is a balance to achieve between decreasing the prevalence of UN and not increasing the prevalence of overweight. In the municipality with a policy document, the person responsible for the kitchens said that ordinary food provided by the kitchens in the policy document municipality was more enriched with carbohydrates and fat than is generally recommended, while this was not done in the other municipalities. This is most likely the explanation why so many residents $(39.4 \%)$ were overweight in the policy document municipality.

The fact that an increase in the use of PE-food was seen is especially important as it has been shown that this action is necessary to take for persons with low-energy problems including fatigue during mealtimes, poor oral intake, and slow eating (27). 'Low energy' is a complex of interacting difficulties that contribute to low BMI and unintentional weight loss if not taken care of (17). The fact that there was no increase in the number of residents getting feeding assistance is not problematic. Eating assistance is mainly provided for residents with ingestion problems, and this type of eating difficulty has not been found to substantially contribute to low BMI or unintentional weight loss (17). Thus, the study circle intervention gives positive effects precisely where earlier research has indicated a need for improvements, i.e. in an increased precision in the provision of PE-food. It is also desirable to increase the provision of oral supplements in between meals to residents at UN-risk.

\section{Conclusion}

A combination of study circles and the implementation of a policy document can possibly give the best outcome regarding an increased precision in the measures taken to prevent or treat UN-risk. Likewise, the precision can most likely increase if there is a specific focus in the study circle discussions on the criteria for defining UN-risk and what measures to take when a resident is at UN-risk. When combining the study circles and policy document interventions, it is important to also consider prevention of overweight.

\section{Acknowledgements}

We thank the residents and the staff, teachers, and students for their cooperation. The study was conducted in cooperation with the Network for Eating and Nutrition in North-East Skåne (NENNES) and the Clinical Research Group within the Knowledge Group for Clinical Nursing Science at Kristianstad University College.

\section{Conflict of interest and funding}

The first author (AW) is supported by the Swedish Research Council and the Skåne County Council's research and development foundation. The study circle intervention was supported by the 'competence ladder,' a government investment in competence improvement for staff in social service. We especially thank The Swedish Institute for Health Sciences (Vårdalinstitutet) for support in the development of the study circle manual focusing on eating and nutrition. The study sponsors were not involved in any parts of the study.

\section{References}

1. Westergren A, Lindholm C, Axelsson C, Ulander K. Prevalence of eating difficulties and malnutrition among persons within hospital care and special accommodations. J Nutr Health Aging 2008; 12: 39-43.

2. Cawood AL, Smith A, Dalrymple-Smith J, Bolch R, Pickles S, Church S, et al. Prevalence of malnutrition and use of nutritional support in Peterborough Primary Care Trust. J Hum Nutr Diet 2008; 21: 384.

3. Labossiere R, Bernard MA. Nutritional considerations in institutionalized elders. Curr Opin Clin Nutr Metab Care 2008; 11: 1-6.

4. Brown LE, Copeman J. Nutritional care in care homes: experiences and attitudes of care home staff. J Hum Nutr Diet 2008; 21: 383 .

5. Khalaf A, Berggren V, Westergren A. The thin patients healthcare staff experiences of caring for undernourished patients in an orthopedic setting. Nurs Ethics 2009; 16: 5-18.

6. Carrier N, West GE, Ouellet D. Cognitively impaired residents' risk of malnutrition is influenced by foodservice factors in longterm care. J Nutr Elder 2006; 25: 73-87. 
7. Turic A, Gordon KL, Craig LD, Ataya DG, Voss AC. Nutrition supplementation enables elderly residents of long-term-care facilities to meet or exceed RDAs without displacing energy or nutrient intakes from meals. J Am Diet Assoc 1998; 98: 1457-9.

8. Milne AC, Avenell A, Potter J. Meta-analysis: protein and energy supplementation in older people. Ann Intern Med 2006; 144: $37-48$

9. Milne AC, Potter J, Avenell A. Protein and energy supplementation in elderly people at risk from malnutrition. Cochrane Database Syst Rev 2005: CD003288.

10. Olin AO, Osterberg P, Hadell K, Armyr I, Jerstrom S, Ljungqvist O. Energy-enriched hospital food to improve energy intake in elderly patients. JPEN J Parenter Enteral Nutr 1996; 20: 93-7.

11. Nijs KA, de Graaf C, Siebelink E, Blauw YH, Vanneste V, Kok FJ, et al. Effect of family-style meals on energy intake and risk of malnutrition in Dutch nursing home residents: a randomized controlled trial. J Gerontol A Biol Sci Med Sci 2006; 61: 935-42.

12. Crogan NL, Shultz JA, Adams CE, Massey LK. Barriers to nutrition care for nursing home residents. J Gerontol Nurs 2001; 27: $25-31$.

13. Simmons SF, Schnelle JF. A continuous quality improvement pilot study: impact on nutritional care quality. J Am Med Dir Assoc 2006; 7: 480-5.

14. Kitson AL, Rycroft-Malone J, Harvey G, McCormack B, Seers $\mathrm{K}$, Titchen A. Evaluating the successful implementation of evidence into practice using the PARiHS framework: theoretical and practical challenges. Implement Sci 2008; 3: 1-12.

15. Landtblom A-M, Lang C, Flensner G. The study circle as a tool in multiple sclerosis patient education in Sweden. Patient Prefer Adhere 2008; 2: 225-32.

16. Strombeck R. The Swedish study circle - possibilities for application to health education in the United States. Health Educ Res 1991; 6: 7-17.

17. Westergren A, Lindholm C, Mattsson A, Ulander K. Mimimal eating observation form: reliability and validity. J Nutr Health Aging 2009; 13: 6-12.

18. SNUS, Samarbetsgruppen för nutritionens utveckling i Sverige. [Cooperation group for the development of nutrition in Sweden] Nutritionsbehandling i sjukvård och omsorg. [Nutritional treatment in care and service] Dietisternas Riksförbund, Nutritionsnätet för sjuksköterskor. Stockholm: Svensk Förening för Klinisk Nutrition, SWESPEN; 2004 [In Swedish].
19. Papers written by researchers within the field of eating and nutrition. Lund: Vårdalinstitutet. www.vardalinstitutet.net/naring; 2008 [cited 21 October 2008].

20. Karlström B, Andersen M. Mat och kostbehandling för äldre: problem och möjligheter [Food and nutritional treatment for elderly people: problems and possibilities]. Uppsala, Sweden: Statens livsmedelsverk; 1998.

21. Nilsson Balknäs U, Andersen M. Mat och näring för sjuka inom vård och omsorg [Food and nutrition for sick people in care and service]. Uppsala, Sweden: Statens livsmedelsverk; 2003.

22. Altman DG. Practical statistics for medical research. London: Chapman and Hall; 1991.

23. Lauque S, Arnaud-Battandier F, Mansourian R, Guigoz Y, Paintin M, Nourhashemi F, et al. Protein-energy oral supplementation in malnourished nursing-home residents. A controlled trial. Age Ageing 2000; 29: 51-6.

24. Desai J, Winter A, Young KW, Greenwood CE. Changes in type of foodservice and dining room environment preferentially benefit institutionalized seniors with low body mass indexes. $\mathbf{J}$ Am Diet Assoc 2007; 107: 808-14.

25. Beck AM, Damkjaer K, Beyer N. Multifaceted nutritional intervention among nursing-home residents has a positive influence on nutrition and function. Nutrition 2008; 24: 1073-80.

26. Suominen MH, Kivisto SM, Pitkala KH. The effects of nutrition education on professionals' practice and on the nutrition of aged residents in dementia wards. Eur J Clin Nutr 2007; 61: 1226-32.

27. Westergren A. Nutrition and its relation to mealtime preparation, eating, fatigue and mood among stroke survivors after discharge from hospital - a pilot study. Open Nurs J 2008; 2: 15-20.

\footnotetext{
*Albert Westergren

Department of Clinical Nursing Science

School of Health and Society

Kristianstad University College

SE-29| 88 Kristianstad

Sweden

Tel: +46 44208550

Email: Albert.Westergren@hkr.se
} 